\title{
UJI AKTIVITAS ANTIOKSIDAN DARI EKSTRAK ETANOL BUNGA KANA MERAH (Canna coccinea Mill) MENGGUNAKAN METODE DPPH
}

\author{
Afrilia Veronika Rumangu ${ }^{1)}$, Adithya Yudistira ${ }^{1)}$, Henki Rotinsulu ${ }^{1)}$ \\ ${ }^{1)}$ Program Studi Farmasi FMIPA UNSRAT Manado, 95115
}

\begin{abstract}
Cana plants are flower ornamental plants whose genus or margins are the only ones in the family Cannacea. This study aims to determine the activity of antioxidant compounds from ethanol extract of Canna coccinea Mill flower. by using the DPPH method. Flowers Canna coccinea Mill extracted using maceration with ethanol as a solvent. As a parameter, testing of antioxidant activity was carried out using the DPPH (1,1 - diphenyl-2-pikrilhidrazil) method which was measured using UV-Vis Spectrophotometry at a wavelength of $517 \mathrm{~nm}$. The result showed that ethanol of Canna coccinea Mill,flower proven to have antioxidant activity in each concentration test. The highest concentration has an free radical scavenging activity by reaching of 56,00\%.
\end{abstract}

Keywords: Flowers Canna coccinea Mill, Antioxidant, Extraction, DPPH

\begin{abstract}
ABSTRAK
Tanaman kana adalah tanaman hias bunga yang genus atau marganya merupakan satu-satunya dalam family Cannaceae. Penelitian ini bertujuan untuk mengetahui aktivitas senyawa antioksidan dari ekstrak etanol bunga Canna coccinea Mill. dengan menggunakan metode DPPH. Bunga Canna coccinea Mill. diekstraksi menggunakan metode maserasi dengan etanol sebagai pelarut. Sebagai parameter, pengujian aktivitas antioksidan dilakukan dengan metode DPPH (1,1-difenil-2-pikrilhidrazil) yang diukur menggunakan Spektrofotometri UV-Vis pada panjang gelombang $517 \mathrm{~nm}$. Hasil penelitian menunjukkan ekstrak etanol bunga Canna coccinea Mill. terbukti memiliki aktivitas antioksidan disetiap konsentrasi pengujian. Konsentrasi tertinggi memiliki aktivitas penangkal radikal bebas dengan mencapai presentase $56,00 \%$.
\end{abstract}

Kata Kunci : Bunga Canna coccinea Mill, Antioksidan, Ekstraksi, DPPH 


\section{PENDAHULUAN}

Indonesia merupakan negara yang memiliki ribuan jenis tanaman yang harus dilestarikan dan dimanfaatkan dengan baik. Sebagian besar tanaman tersebut dapat digunakan sebagai obat tradisional. Obat tradisional yang berasal dari bahan -bahan alami, memiliki efek samping, tingkat bahaya dan resiko yang jauh lebih rendah dibandingkan dengan obat kimia (Sunaryanti, 2012).

Salah satu tanaman yang dapat digunakan sebagai obat tradisional adalah tumbuhan kana merah. Tanaman Kana merah mempunyai nama ilmiah Canna coccinea Mill, pada awalnya merupakan tanaman hias yang tidak diketahui manfaatnya. Di Indonesia tanaman kana merah (Canna coccinea Mill.) merupakan salah satu tanaman hias yang berpotensial sebagai obat alternatif (Sunaryanti, 2012).

Pada tanaman kana merah atau lebih sering disebut di Indonesia bunga tasbih/ganyang hutan ternyata mempunyai banyak manfaat yang belum banyak orang ketahui. Setelah diteliti, diketahui bahwa tanaman kana merah mengandung aktivitas antioksidan yang sangat bermanfaat bagi tubuh, yang memiliki kemampuan menghilangkan oksigen tunggal dan berinteraksi dengan senyawa radikal bebas (Dutta, et al., 2004)

Radikal bebas merupakan salah satu bentuk senyawa reaktif, yang secara umum diketahui sebagai senyawa yang memiliki elektron yang tidak berpasangan di kulit terluarnya. Radikal bebas sebagai molekul atom dengan elektron bebas dalam jumlah normal dapat berfungsi dalam

membunuh virus dan bakteri, namun dalam jumlah yang sangat besar zat ini dapat merusak jaringan normal, menganggu produksi DNA, merusak dinding sel khususnya lapisan lipid, serta mempengaruhi pembuluh darah. Radikal bebas dapat ditangkal atau diredam dengan pemberian antioksidan (Halliwel, 2004).

Antioksidan berupa senyawa kimia yang dapat menyumbangkan satu atau lebih elektron kepada radikal bebas, sehingga reaksi radikal bebas tersebut dapat terhambat. Penggunaan senyawa antioksidan berkembang dengan pesat, baik untuk makanan maupun pengobatan. Penggunaannya sebagai obat semakin meningkat dengan bertambahnya pengetahuan tentang aktivitas radikal bebas terhadap beberapa penyakit degeneratif seperti penyakit jantung, diabetes, kanker, inflamasi jaringan, kelainan imunitas dan penuaan dini (Halliwel, 2004).

Salah satu metode yang sering dipakai dalam menguji aktivitas antioksidan yaitu metode DPPH (1,1-difenil-2pikrilhidrazil). Dari penelitian-penelitian tentang bunga yang telah dilakukan sebelumnya mendorong peneliti untuk melakukan penelitian untuk membuktikan bahwa bunga Canna coccinea Mill. memiliki kandungan karotenoid sebagai antioksidan. Berdasarkan latar belakang diatas, maka peneliti terdorong untuk melakukan penelitian dengan judul "Aktivitas Antioksidan Ekstrak Etanol Bunga Kana Merah (Canna coccinea Mill) Menggunakan Metode DPPH”.

\section{METODOLOGI PENELITIAN}

\section{Waktu dan Tempat Penelitian}

Pengambilan sampel dilakukan desa Rurukan, di kota Tomohon Sedangkan untuk preparasi sampel, pengamatan dan analisis data penelitian ini dilakukan di Laboratorium Penelitian Farmasi lanjutan (Farmakognosi Fitokimia dan Laboratorium Analisis Farmasi) Program Studi Farmasi, Fakultas Matematika dan Ilmu Pengetahuan Alam, Universitas Sam Ratulangi pada bulan Desember 2018 - Januari 2019. 
Alat

Alat yang digunakan dalam penelitian ini ialah wadah botol air kemasan $600 \mathrm{~mL}$, cawan porselin, sarung tangan, telenan, gelas ukur, erlenmeyer, kaca arloji, labu ukur (100 mL dan $50 \mathrm{~mL})$, tabung reaksi, rak tabung reaksi, baker glass, vortex (Benchmark), corong, pipet tetes, mikro pipet, timbangan digital (AE ADAM), spatula, oven dan spektrofotometer UV-Vis (UV-1800).

\section{Bahan}

Bahan yang digunakan dalam penelitian ini yaitu kertas saring, tissue, alumunium foil, kertas label, etanol 96\%, serbuk DPPH (1,1-difenil-2-pikrilhidrazil), Bunga Canna coccinea Mill. dan serbuk vitamin c p.a sebagai kontrol positif (pembanding).

\section{Bentuk Penelitian}

Penelitian dilakukan dengan metode DPPH dalam bentuk eksperimental laboratorium.

\section{Prosedur Penelitian}

\section{Pengambilan Sampel}

Sampel diambil di Rurukan, Kota Tomohon, Provinsi Sulawesi Utara. Bagian yang digunakan dari tumbuhan ini ialah bunga, sebanyak 1500gr.

\section{Preparasi Sampel}

Bunga Canna coccinea Mill yang telah dipetik dan dicuci, kemudian dimasukan ke dalam toples untuk perlakuan selanjutnya.

\section{Ekstraksi}

Sampel yang telah dimasukan kedalam toples kemudian dimaserasi dengan pelarut etanol sebanyak $4000 \mathrm{~mL}$ selama 3 kali 24 jam sesekali sambil diaduk. Hasil ekstraksi kemudian disaring untuk mendapatkan filtrat. Kemudian filtrat yang diperoleh setiap pergantian larutan digabungkan dan diuapkan dengan rotary evaporator hingga mendapatkan ekstrak kental dari bunga Canna coccinea Mill.

\section{Pembuatan Larutan Stok 100 ml}

Sebanyak $100 \mathrm{mg}$ ekstrak bunga Canna coccinea Mill.dilarutkandidalam etanol 96\% ad.100 mL (konsentrasi 1000 ppm). Dengan masing-masing konsentrasi $100 \mathrm{mg} / \mathrm{L}, 75 \mathrm{mg} / \mathrm{L}, 50 \mathrm{mg} / \mathrm{L}$, dan $25 \mathrm{mg} / \mathrm{L}$ dihitung dengan menggunakan rumus pengenceran, yaitu :

$$
\mathbf{M}_{1} \cdot \mathbf{V}_{1}=\mathbf{M}_{2} \cdot \mathbf{V}_{2}
$$

Pada keempat konsentrasi, masingmasing hasil yang didapatkan dari hasil $\mathrm{V}_{1}$ dipipet dan ditambahkan etanol $96 \%$ hingga mencapai tanda batas (10 mL), kemudian dipindahkan ke dalam tabung reaksi dan ditutup dengan menggunakan aluminium foil untuk digunakan pada perlakuan selanjutnya.

\section{Pembuatan Larutan DPPH}

Penentuan aktivitas penangkal radikal bebas DPPH menurut Burda dan Olezek (2001). Sebanyak $4 \mathrm{mg}$ serbuk DPPH ditimbang dan dilarutkan dalam etanol 96\% sebanyak $100 \mathrm{~mL}$. Selanjutnya larutan stok DPPH dilakukan pengujian kontrol, di uji pada spektrofotometer UVVis dengan panjang gelombang antara 400$800 \mathrm{~nm}$.

\section{Pengujian Larutan Kontrol DPPH dan Pengujian Sampel}

Setelah pengujian sampel dan pengujian kontrol, dilanjutkan pada pengujian vitamin $\mathrm{C}$ p.a sebagai kontrol pembanding. Kaca arloji ditimbang, vitamin 
$\mathrm{C}$ ditimbang sebanyak $10 \mathrm{mg}$. Kemudian, vitamin C p.a dilarutkan dalam etanol $96 \%$ sebanyak $10 \mathrm{~mL}$, buat larutan stok dengan konsentrasi yang sama sebelumnya yaitu konsentrasi $100 \mathrm{mg} / \mathrm{L}, 75 \mathrm{mg} / \mathrm{L}, 50 \mathrm{mg} / \mathrm{L}$ dan $25 \mathrm{mg} / \mathrm{L}$ dengan ditambahkan masingmasing larutan dengan etanol p.a mencapai tanda batas $(10 \mathrm{~mL})$, dengan pengulangan sebanyak 3 kali pada masing-masing konsentrasi. Pada masing-masing konsentrasi di pipet $2 \mathrm{~mL}$ dan ditambahkan larutan DPPH $2 \mathrm{~mL}$, di vorteks selama 2 menit dan diinkubasi selama 30 menit pada suhu $37^{\circ}$ C. Sampel vitamin C p.a diuji pada spektrofotometer UV-Vis dengan panjang gelombang $517 \mathrm{~nm}$.

\section{Pengujian Aktivitas Antioksidan Dengan Metode DPPH}

Penentuan aktivitas penangkal radikal bebas DPPH menurut Burda dan Olezek (2001).Diambil sebanyak $2 \mathrm{~mL}$ ekstrak bunga Canna coccinea Mill. dengan konsentrasi $100 \mathrm{mg} / \mathrm{L}, 75 \mathrm{mg} / \mathrm{L}, 50 \mathrm{mg} / \mathrm{L}$ dan $25 \mathrm{mg} / \mathrm{L}$ ditambahkan masing-masing 1,5 mL larutan DPPH dalam etanol dan divorteks selama 2 menit. Berubahnya warna ungu menjadi warna kuning menunjukkan efisiensi penangkal radikal bebas.Diukur absorbansi pada spektrofotometer UV-Vis dengan panjang gelombang $517 \mathrm{~nm}$ setelah diinkubasi selama 30 menit.Kemudian diamati perbandingannya dengan vitamin C p.a sebagai standar. Setelah absorbansi didapat, Aktivitas penangkapan radikal bebas (persen inhibisi) dihitung sebagai persentase berkurangnya warna DPPH dengan menggunakan rumus berikut:

$$
\begin{aligned}
& \% \text { inhibisi } \\
& =1-\frac{\text { absorbansi sampel }}{\text { absorbansi kontrol }} \times 100 \%
\end{aligned}
$$

\section{HASIL DAN PEMBAHASAN}

Dari hasil pengukuran pada penilititian ini diperoleh absorbansi yang kemudian digunakan untuk perhitungan nilai persen inhibisi atau persen perendaman senyawa antioksidan terhadap DPPH. Data persen inhibisi ekstrak etanol bunga Canna coccinea Mill. dan Vitamin C p.a sebagai pembanding disajikan pada Tabel 1 berikut ini :

Tabel 1. Hasil pengujian Perbandingan antara Ekstrak Etanol Bunga Canna coccinea Mill dan

\begin{tabular}{|c|c|c|c|c|c|}
\hline \multirow{2}{*}{\multicolumn{2}{|c|}{ Pengulangan }} & \multicolumn{4}{|c|}{ Konsentrasi } \\
\hline & & \multirow{2}{*}{$\begin{array}{c}\text { I } \\
49,10 \\
\%\end{array}$} & \multirow{2}{*}{$\begin{array}{c}\text { II } \\
\mathbf{4 8 , 8 0} \\
\%\end{array}$} & \multirow{2}{*}{$\begin{array}{c}\text { III } \\
\mathbf{4 8 , 5 0} \\
\%\end{array}$} & \multirow{2}{*}{$\begin{array}{c}\text { Rata- } \\
\text { Rata } \\
\mathbf{4 8 , 8 0} \\
\%\end{array}$} \\
\hline $\begin{array}{c}25 \\
\mathrm{mg} /\end{array}$ & $\begin{array}{c}\text { Ekstr } \\
\text { ak }\end{array}$ & & & & \\
\hline $\mathbf{L}$ & Vit.C & $\begin{array}{c}66,70 \\
\%\end{array}$ & $\begin{array}{c}67,40 \\
\%\end{array}$ & $\begin{array}{c}74,70 \\
\%\end{array}$ & $\begin{array}{c}96,60 \\
\%\end{array}$ \\
\hline \multirow{2}{*}{$\begin{array}{c}\mathbf{5 0} \\
\mathbf{m g} / \\
\mathbf{L}\end{array}$} & $\begin{array}{c}\text { Ekstr } \\
\text { ak } \\
\end{array}$ & $\begin{array}{c}\mathbf{5 0 , 5 0} \\
\% \\
\end{array}$ & $\begin{array}{c}49,90 \\
\%\end{array}$ & $\begin{array}{c}49,70 \\
\%\end{array}$ & $\begin{array}{c}50,03 \\
\%\end{array}$ \\
\hline & Vit. C & $\begin{array}{c}\mathbf{8 8 , 1 0} \\
\%\end{array}$ & $\begin{array}{c}89,30 \\
\%\end{array}$ & $\begin{array}{c}90,00 \\
\%\end{array}$ & $\begin{array}{c}89,13 \\
\%\end{array}$ \\
\hline \multirow{2}{*}{$\begin{array}{c}75 \\
\mathrm{mg} / \\
\mathrm{L}\end{array}$} & $\begin{array}{c}\text { Ekstr } \\
\text { ak }\end{array}$ & $\begin{array}{c}52,60 \\
\%\end{array}$ & $\begin{array}{c}52,40 \\
\%\end{array}$ & $\begin{array}{c}51,40 \\
\%\end{array}$ & $\begin{array}{c}52,10 \\
\%\end{array}$ \\
\hline & Vit. C & $\begin{array}{c}90,20 \\
\%\end{array}$ & $\begin{array}{c}90,10 \\
\%\end{array}$ & $\begin{array}{c}90,20 \\
\%\end{array}$ & $\begin{array}{c}90,16 \\
\%\end{array}$ \\
\hline \multirow{2}{*}{$\begin{array}{c}100 \\
\mathrm{mg} / \\
\mathrm{L}\end{array}$} & $\begin{array}{c}\text { Ekstr } \\
\text { ak }\end{array}$ & $\begin{array}{c}\mathbf{5 8 , 5 0} \\
\%\end{array}$ & $\begin{array}{c}55,70 \\
\%\end{array}$ & $\begin{array}{c}54,10 \\
\%\end{array}$ & $\begin{array}{c}56,00 \\
\%\end{array}$ \\
\hline & Vit. C & $\begin{array}{c}90,20 \\
\% \\
\end{array}$ & $\begin{array}{c}89,60 \\
\% \\
\end{array}$ & $\begin{array}{c}90,20 \\
\% \\
\end{array}$ & $\begin{array}{c}90,00 \\
\% \\
\end{array}$ \\
\hline
\end{tabular}
Vitamin C p.a

Uji aktivitas pada suatu tanaman sangat penting dilakukan untuk mengetahui apakah dari tanaman tersebut terbukti memiliki aktivitas antioksidan yang dapat menangkal radikal bebas. Pada penelitian ini, tanaman yang digunakan yaitu tanaman Canna coccinea Mill. Diketahui tanaman pigmen bunga Canna coccinea Mill. memiliki kandungan senyawa Flavonoid, tepatnya antosianin., sehingga tidak menutup kemungkinan untuk bagian bunga dari tanaman Canna coccinea Mill. juga dapat mengandung senyawa aktivitas antioksidan yang dapat mempertahankan diri 
dari lingkungan maupun serangan dari organisme lain.

Pengujian antioksidan pada penelitian ini, menggunakan metode DPPH (1,1-difenil-2-pikrilhidrazil). Pemilihan metode ini karena merupakan metode yang sangat sederhana, mudah, cepat dan peka serta hanya memerlukan sedikit sampel untuk evaluasi aktivitas antioksidan. DPPH (1,1-difenil-2-pikrilhidrazil) merupakan radikal bebas sintetik berwarna ungu yang banyak digunakan dalam uji aktivitas antioksidan. Larutan radikal bebas DPPH memiliki atom nitrogen yang tidak berpasangan. Reaksi DPPH dengan atom hidrogen yang terdapat dalam antioksidan dapat membuat larutan DPPH menjadi berkurang reaktivitasnya, yang ditunjukkan dengan memudarnya warna ungu menjadi kuning. Perubahan warna ini mengakibatkan perubahan absorbansi pada panjang gelombang maksimum DPPH menggunakan spektrofotometri UV-Vis yang menjadi patokan (Molyneux, 2004). Penetuan panjang gelombang serapan maksimum $(\lambda$ maks) larutan DPPH dilakukan dengan mengukur absorbansi larutan pada panjang gelombang antara 400-800 $\mathrm{nm}$. Hasil yang didapatkan pada penelitian ini adalah 517 nm dan memiliki absorbansi kontrol 0,753nm (Lampiran6 ).

Pengujian aktivitas antioksidan dalam penelitian ini menggunakan perbandingan 1:1 yang artinya $2 \mathrm{ml}$ larutan DPPH dicampurkan dengan $2 \mathrm{ml}$ larutan sampel (ekstrak etanol bunga Canna coccinea Mill. atau vitamin C) pada tiap konsentrasi yang berbeda-beda. Sempurnya campuran DPPH dan ekstrak dibantu dengan perlakuan di vortex selama 2 menit. Berkurangnya intensitas warna larutan DPPH tersebut dapat menunjukkan bahwa terjadi reaksi antara atom hidrogen yang dilepas oleh bahan uji dengan molekul radikal DPPH sehingga terbentuk senyawa 1,1-difenil-2-pikrilhidrazil yang berwarna kuning. Pada penelitian ini, ekstrak etanol dari bunga Canna coccinea Mill. yang telah ditambahkan larutan DPPH, Tidak mengalami adanya perubahan warna, tetapi penelitian ini tetap dilanjutkan.

Konsentrasi ekstrak etanol bunga Canna coccinea Mill. yang digunakan adalah $100 \mathrm{mg} / \mathrm{L}, 75 \mathrm{mg} / \mathrm{L}, 50 \mathrm{mg} / \mathrm{L}$, dan 25 $\mathrm{mg} / \mathrm{L}$. Masing-masing konsentrasi dicampurkan dengan larutan DPPH dengan perbandingan yang ada. Campuran dihomogenkan dan diinkubasi selama 30 menit pada tempat gelap dengan suhu $37^{\circ} \mathrm{C}$. Hal ini dilakukan untuk menghindari kontaminasi dan mengoptimalkan aktivitas DPPH agar terjadi reaksi antara DPPH dengan sampel yang diuji. Setelah diinkubasi, kemudian masing-masing ekstrak dilakukan pengukuran absorbansi dengan menggunakan spektrofotometer pada panjang gelombang serapan maksimum $(\lambda$ maks) DPPH $517 \mathrm{~nm}$. Pada tiap konsentrasi dilakukan sebanyak 3 kali pengulangan.

Pembanding yang digunakan sebagai kontrol positif adalah Vitamin C p.a dimana sebagai pembanding karena berfungsi sebagai antioksidan sekunder yaitu menangkap radikal bebas, mencegah terjadinya reaksi berantai, aktivitas antioksidannya sangat tinggi, mudah diperoleh dan vitamin $\mathrm{C}$ lebih polar dari vitamin yang lain. Vitamin $\mathrm{C}$ mempunyai gugus hidroksi bebas yang bertindak sebagai penangkap radikal bebas.

Berdasarkan hasil yang diperoleh pada Tabel 1 menunjukkan bahwa pengukuran persen inhibisi pada ekstrak etanol bunga Canna coccinea Mill. memiliki aktivitas antioksidan dan mengalami peningkatan dari konsentrasi $25 \mathrm{mg} / \mathrm{L}$ sampai dengan $100 \mathrm{mg} / \mathrm{L}$. Pada ekstrak etanol bunga Canna coccinea Mill. dengan konsentrasi $100 \mathrm{mg} / \mathrm{L}$ memiliki persen inhibisi rata-rata paling tinggi yaitu sebesar $56,00 \%$. Penigkatan persen inhibisi pada ekstrak bunga Canna coccinea Mill. 
menandakan bahwa konsentrasi ekstrak yang ditambahkan mempengaruhi kemampuan ekstrak dalam merendam radikal bebas. Hal ini didukung oleh penelitian yang dilakukan oleh Hanani et al., (2005) yang menyatakan bahwa presentasi penghambat atau persen inhibisi terhadap aktivitas radikal bebas akan ikut meningkat seiring dengan meningkatnya konsentrasi. Hasil pengujian perbandingan aktivitas antioksidan ekstrak bunga Canna coccinea Mill. Dan Vitamin C (Tabel 1) juga menunjukkan bahwa aktivitas antioksidan ekstrak etanol bunga Canna coccinea Mill. lebih rendah dibandingkan dengan Vitamin C.

Rendahnya aktivitas antioksidan ini kemungkinan disebabkan oleh berbagai faktor, diantaranya karena metode ekstraksi yang digunakan kemungkinan tidak cukup menarik komponen kimia yang bersifat antioksidan dalam bunga Canna coccinea Mill. selain itu karena vitamin C merupakan senyawa murni sedangkan ekstrak etanol bunga Canna coccinea Mill. masih merupakan senyawa campuran dan belum diketahui kandungan senyawanya yang bersifat antioksidan, dimana adanya senyawa yang tidak bersifat antioksidan kemungkinan bisa mempengaruhi aktivitas antioksidan ekstrak etanol bunga Canna coccinea Mill. itu sendiri.

\section{KESIMPULAN}

Berdasarkan dari hasil penelitian yang telah dilakukan maka, dapat disimpulkan bahwa ekstrak etanol bunga Canna coccinea Mill. dari rurukan, Kota Tomohon memiliki aktivitas antioksidan disetiap konsentrasi. Aktivitas antioksidan tertinggi terlihat pada konsentrasi $100 \mathrm{mg} / \mathrm{L}$ dengan mencapai presentase $56,00 \%$.

\section{SARAN}

Perlu dilakukan penelitian lebih lanjut pada bunga Canna coccinea Mill. dengan menggunakan metode yang lain seperti metode Cuprac, Frap dan sebaiknya membandingkan hasilnya dengan penelitian ini.

\section{DAFTAR PUSTAKA}

Dutta, D.,Chaudhuri,U.R. \& Chakraborty, R. (2004). Retention of $\beta$-carotene in frozen carrots under frying condition of temperature and time of storage. Jadavpur University, Kolkata-700032, India.

Halliwell, B., Whiteman, M. 2004. Measuring reactive species and oxidative damage in vivo and in cell culture: how should you do it and what do the results mean? $\mathrm{Br} J$ Pharmacol, 142, 231-55.

Molyneux, P. 2004. The Use of The Stable Free Radical Diphenylpicrylhydrazyl (DPPH) For Estimating Antioxidant Activity. J.Sci. Technol. 26(2) : 211219. Narins, D.M.C. 1996. Vitamin Dalam Krause's FOOD, Nutrition and Diet Therapy. Mahlan, L.K, hal 110-114.

Sunaryanti, D.P. 2012. Analisis Keanekaragaman Tanaman Kana (Canna sp.) Berdasarkan Karakter Morfologi. Naskah S1. Fakultas Sains dan Teknologi, Universitas Airlangga, Surabaya. 